\title{
Analysis of the Practical Value of Czerny Piano Etudes
}

\author{
Aiyong Xin \\ Anshan Normal University \\ Anshan, China
}

\begin{abstract}
As an outstanding piano educator, Czerny not only do a lot of a piano etudes, more important is his achievement in the establishment of a complete set of training system of piano teaching practice in the long-term study. The teaching strategy of this system is guiding the development of piano playing in a healthy and stable direction. In Czerny Etude system, he integrated the classical style of Athens and Clementi's dynamic style and integrates the two into one. After careful arrangement and careful classification, the piano learners are practiced in different degrees from the shallow to the depth. This article starts with the Czerny piano etude creation techniques and the technical characteristics of the skills, analysis the significance of its practical analysis.
\end{abstract}

\section{Keywords-Czerny; piano etude; performance}

\section{INTRODUCTION}

Czerny's Life was through the golden age of piano art development in Europe, which was a prosperous period of the late classical and romantic; this period is an important turning point in the art of piano teaching and playing method from classical to modern romanticism. The value of his piano etudes not only reflected in the piano's promotion and development, but he successfully cultivated a group of superior technology, excellent and outstanding inspiration active junior pianist, Czerny Etudes is his most valuable contribution made for piano art field.

\section{CZERNY'S LIFE AND THE CZERNY ETUDES}

Czerny, Carle Czerny was born in Austria in February 21, 1791 in Vienna, died on July 15, 1857 in the same place .He was not only a pianist, but also a very active composer and music educator. Early nineteenth Century is the founder of Czerny piano school in Vienna, he summed up the romantic piano before playing the piano on finger force skills, but also stressed the importance of arm weight. He is world-famous for his etudes, and is known as the king of etudes. He played a bridge in the art of piano playing in classicism and romanticism. As a student of Beethoven, Lester's teacher, in nineteenth Century Czerny occupies a unique position in the history of piano performance.

\section{THE INTRODUCTION OF CZERNY PIANO ETUdES}

Czerny wrote a number of piano etudes which has a total of 78.His Etude is a basic piano teaching material, which emphasizes the degree of freedom of wrist movement while strengthening the development of fingering skills, and has a deeper inquiry into music emotion and music effect.

In most of these vast Czerny's pieces, his piano etudes is the most practical, well-known and widely used. $\mathrm{He}$ is famous with his etudes and is known as the "king of Etudes". $\mathrm{He}$ built a bridge for piano playing in both classicism and romanticism. In early nineteenth century, the first phase of the industrial revolution in Europe, making and practical performance of piano has been in the development period of uncertainty, then by virtue of diligence and Czerny's extraordinary creative ability will be the piano playing style and playing a variety of diverse combination of technology, and edited the book. In the book of "the complete works of piano theory and practice" published to Queen Victoria in 1839 , these styles and techniques were summarized. Czerny piano etudes covers a variety of degree in the learning process, from simple to complex has been extended to specific, or to use the virtuoso Concert Etudes, some Etudes for various distinctive style of music creation. There are a lot of Czerny piano etudes, including the number of total of 78 , 78 of the etude is a result of the era of rapid change. Now these etudes which frequently used by piano learners has nearly more than 60 books. These exercises are very valuable piano teaching materials. For many years, it has been widely used all over the world music college.

\section{CZERNy PiAno EtUdes TeChNiCAL CHARACTERISTIC VALUE}

Czerny summarized the piano skills on finger force before the romantic period, at the same time also showed the importance of arm weight, he pointed out in "the piano playing theory": "when playing, hand movements should be hided, fingers cannot lift higher than the normal time. In order to do it correctly, it is necessary to strengthen the internal tension of the muscles and to add the weight of the arm in the range of the soft movement of the finger. Czerny etudes by emphasizing the development of fingering technique, attaches great importance to the wrist action, requires certain freedom while crescendo, diminuendo effect In addition, Czerny Etudes in writing methods although no major differences and some classical composers, but in dealing with the requirements for the use of instruments have obvious differences. In addition, although the writing method of Czerny exercise doesn't have any difference from some 
classical composers, it has obvious differences in dealing with the requirements for the use of instruments. He is on the keyboard use range is wider, there is also a new exploration and Research on the sound effects such as Op.740, No.38 in order to have sound contrast, he personally marked "hammer like" and "beautiful and little coherence; in Op.740, No.4 labeled" bells, bell tube sound ", in terms of performance speed and pedal is also provided by himself. Czerny's writing style is decided by his own artistic quality, so in his works, though it doesn't lack the beautiful melodious tunes, but the cadenza in some works is inevitable with the early nineteenth Century show at the salon style in Czerny etudes, from the techniques involved in playing method and pattern texture etc., are collected in the former and contemporary, and breakthrough and innovation. He opened up a new era of piano playing, making the contemporary pianists the most possible in training and playing skills. So his student Lester always told his students: "to play the Czerny Etudes diligently." His etudes have influenced countless people in the piano territory, and it is still a required course for piano learning. The ancestors of the writing of Clementi Czerny etudes written classical format, used to emphasize average fluency and tone, to focus on the position, rhythm simple unity, skills of species are standardized, the degree of difficulty of the smaller gap. The Czerny Etudes compared the writing structure more concise and standard, learning more easily and playing back the spectrum, and comparison of the development of Jane. It strengthen the function of stress, frequently use of the factor of the charms of melody, highlighting the theme tune, fusion in various figures, and enrich the harmonic accompaniment .This gives the etudes more vivid and expressive power. The application of classification and technology is not only wide and typical, but also focuses on the actual benefits of training.

\section{The VAlue of CZERny Piano Etudes ReFleCted IN PIANO EDUCATION}

Piano education was introduced into China in the last century. Its appearance and development is less than one hundred years, but it has gained brilliant achievements that the world has noticed. It can be said that in piano education, China is the fastest developing country. The Czerny piano exercises the role and the role is very great, this is the consensus of all piano lovers .So far, although from the aspect of piano skills, his etudes have some sidedness and limitations in the technical and creative characteristics of playing. But in the teaching of piano is still widespread use of Czerny etudes, especially in some degree of learning stage only to learn his etudes, this would have to admit the extensive Czerny piano training and practical. Czerny etudes are as basic materials of piano playing and learning, the main etudes Czerny series:

Works 599 -- a preliminary Piano Course Works 849 -"Piano fluency Etude"

Works 299 -- "Piano fast Etude"

Works 740 - "50 Piano Etudes" (the skillful technical exercises of the fingers)
In addition, there are some works of Czerny Etudes for special nature, such as Works 553, Works 718, Works 636, Works 748 etc. In these etudes works, piano technique subject to technical difficulty number "Czerny Etudes Op.740" the highest and most widely involved, the strongest performing music. The characteristics of the piano education is now the point of view, the "Czerny Czerny Etudes" Op.740 has very strong application value in teaching and learning to play us, so in today's piano teaching, learning, playing on "Czerny Etudes Op.740" use is very extensive. It can be said that as long as it is to achieve this level of piano learning and enthusiasts, it will choose this set of etudes to improve the level of piano performance. In many piano learners, learning the piano every person will use a variety of different degrees of Czerny piano exercises to improve their performance level, now almost become a name Czerny piano etude pronoun, for the majority of known pianist and piano art lovers.

\section{CONCLUSION}

The piano music of the outstanding technology Czerny piano music education, home of his powerful unparalleled, rich and colorful and profound content of the piano teaching practice, accurately established his position in the image of classical piano music history and brilliant. His etudes are not only a very large number, but also the range of techniques involved is very wide, and it has obvious practical significance for the piano education. These exercises have strong inner music performance, skill, practicality, the times, its value is not only reflected in the promotion and development of piano and piano education, more success lies in training a group of outstanding, excellent technology inspiration active and outstanding after generation pianist, this is Czerny Piano Etudes for the most valuable contribution of music, to make the field of piano art.

\section{REFERENCES}

[1] Tingge Wei. Piano learning guide [M]. Beijing: the people's music publishing house, 1997.115.

[2] John Hoffman. On piano playing [M]. Beijing: the people's music publishing house, 1984.50 .

[3] Xiaosheng Zhao. The way of piano performance [M]. Shanghai: World Book Inc, Shanghai, 1999.81

[4] Maolin Li 's piano etudes 740 technical dexterity playing tips [M] Beijing: the people's music publishing house, 2001. 